\title{
Recusa a tratamento de saúde com fundamento em crença religiosa e o dever do Estado de proteger a vida humana. O caso da transfusão de sangue em Testemunha de Jeová
}

Flávio de Araújo Willeman*

\section{Introdução}

Delimitação do problema

A ideia de escrever este ensaio surgiu com o enfrentamento de um caso concreto na Procuradoria-Geral do Estado do Rio de Janeiro, o que motivou reflexões sobre a postura da administração pública, mais especificamente dos médicos que atuam nos hospitais públicos, quando se encontram com o problema da objeção de consciência religiosa por Testemunhas de Jeová, que preferem a morte a receberem tratamento que envolva transfusão de sangue, ainda que necessário e indispensável para salvar a vida.

O caso concreto relata expediente do Hospital Estadual Pedro Ernesto, dando conta da internação de uma jovem paciente, de apenas 21 anos de idade, no Centro de Terapia Intensiva (CTI) com quadro de síndrome de angústia respiratória, necessitando receber ventilação mecânica, bem assim de procedimento de biópsia

\footnotetext{
* Procurador do estado do Rio de Janeiro e advogado. Mestre em direito pela Universidade Candido Mendes. Professor dos cursos de graduação e pós-graduação da Universidade Candido Mendes. Professor dos cursos de pós-graduação da Fundação Getulio Vargas (FGV) e da Universidade Federal Fluminense (UFF). Autor dos livros: Responsabilidade civil das agências reguladoras (2005) e Direito administrativo (2009), publicados pela Lumen Juris.
} 
do pulmão, sendo ainda provável - à época - a necessidade de transfusão de sangue, já que a paciente estava classificada como "gravemente enferma".

Os médicos e professores do hospital suscitaram dúvida acerca do procedimento a ser adotado, do ponto de vista jurídico, uma vez que a paciente apresentou ao hospital documento padronizado, com algumas partes datilografadas e outras preenchidas à mão, por ela assinado juntamente com duas testemunhas, se declarando Testemunha de Jeová e que, mesmo se estivesse correndo perigo de morte, não desejava receber transfusão de sangue.

Diante da posição técnica adotada pela comunidade médica, contrária à manifestação religiosa igual à versada pela jovem paciente antes referida (que vem acontecendo em vários cantos deste país), mais especificamente pela obrigatoriedade de realização de transfusão de sangue em pacientes que estejam correndo risco de morte, independentemente de crença religiosa, puseram-se em xeque ou em aparente contradição dois valores constitucionais: direito à crença religiosa e o exercício de seus fundamentos versus o dever do Estado de garantir a intangibilidade e a inviolabilidade do direito à vida humana. Eis o problema a ser enfrentado neste estudo.

\section{Estado laico. Liberdade de crença e religião. Testemunhas de Jeová}

Conforme conhecimento convencional, o Brasil adotou posição constitucional pela laicidade do Estado. Isto quer dizer que todos os cidadãos são livres para escolher a religião que melhor convier à sua consciência e crença (art. 5으, VI, da CRFB/88). ${ }^{1}$ De outro lado, não é possível aos entes federativos adotarem religião oficial e, tampouco, fomentarem religiões ou opor empecilhos e dificuldade ao livre exercício pelos estabelecimentos religiosos, devotos e seguidores (art. 19, I, da CRFB/88). ${ }^{2}$

Sem dúvida, a laicidade estatal e o princípio democrático proporcionaram - e proporcionam - o surgimento e a difusão de diversas espécies de religião e seitas no Brasil que convivem, salvo raríssimas turbulências, de forma harmônica.

Entre as religiões professadas no Brasil está aquela seguida pelas Testemunhas de Jeová, surgida nos EUA, no final do século XIX. A propósito, vejamos

\footnotetext{
1 "Art. $5^{\text {o }}$ [...]: VI - é inviolável a liberdade de consciência e de crença, sendo assegurado o livre exercício dos cultos religiosos e garantida, na forma da lei, a proteção aos locais de culto e a suas liturgias." 2 "Art. 19. É vedado à União, aos Estados, ao Distrito Federal e aos Municípios: I - estabelecer cultos religiosos ou igrejas, subvencioná-los, embaraçar-lhes o funcionamento ou manter com eles ou seus representantes relações de dependência ou aliança, ressalvada, na forma da lei, a colaboração de interesse público."
} 
as lições doutrinárias de Maria de Fátima Freire de Sá e Ana Carolina Brochado Teixeira que, inclusive, apresentam os fundamentos teológicos que impedem as Testemunhas de Jeová de receberem transfusão de sangue e também as hipóteses em que se admite o perdão pela transfusão de sangue realizada para salvar a vida do paciente.

Os testemunhas-de-jeová têm origem no final do século XIX na América do Norte e hoje possuem seguidores em grande parte do mundo europeu, assim como na América do Sul. Seus integrantes consideram proibida a transfusão de sangue e se baseiam em algumas passagens da Bíblia. Assim, no livro Gênesis (9:3-4) está escrito: “Todo animal movente que está vivo pode servirvos de alimento. Como no caso da vegetação verde, deveras vos dou tudo. Somente a carne com sua alma - seu sangue - não deveis comer". Também no Levítico (17:10) outra passagem é aclamada: “Todo israelita ou todo estrangeiro que habita no meio deles, que comer qualquer espécie de sangue, voltarei minha face contra ele, e exterminá-lo-ei do meio de seu povo." Para esta comunidade religiosa, são três as situações possíveis: $1^{\underline{a}}$ ) Se o médico proceder à transfusão de sangue em um indivíduo contra sua vontade, o testemunha-de-jeová não desrespeitou a própria consciência, razão pela qual não se pode condená-lo; $2^{\underline{a}}$ ) Se um membro religioso aceita sangue em um momento de debilidade e arrepende-se posteriormente, há que se lhe oferecer ajuda espiritual; e $3^{a}$ ) Se um testemunha-de-jeová aceitar a transfusão de maneira voluntária, sem dúvidas ou pesar, estará desrespeitando princípio moral de sua fé que, voluntariamente, decidiu seguir, razão pela qual deverá ser excluído da seita. Embora tenha feito tal escolha, caso venha a se arrepender posteriormente, poderá voltar a praticar a fé (Cortés, 2001:239).

A seita Christian Science (Church of Christ Scientist), fundada em Boston, em 1879, por Mary Baker Eddy, possui adeptos em mais de cinquenta países, principalmente na América e Europa ocidental. Também entende não ser possível a transfusão de sangue, mesmo em situação extrema de perigo de vida. Neste caso, o alcance da objeção de consciência é muito mais extenso do que no que se refere aos testemunhas-de-jeová, porque consideram que qualquer doença pode ser curada mediante oração, defendendo a ilicitude de tratamentos médicos generalizados. Somente alguns de seus membros aceitam a ingestão de remédios para alívio da dor (Sá e Teixeira, 2005:130). (Grifos nossos)

Conforme se percebe, os seguidores da religião Testemunhas de Jeová trazem consigo, como princípio religioso, decorrente de interpretação de passagens bíblicas, a impossibilidade de realização de tratamentos médicos que importem em transfusão de sangue, mesmo que esteja em risco a vida do paciente/crente. 
Pergunta importante para se tentar solucionar o problema consiste em saber se é aceitável, do ponto de vista constitucional, que alguém, sob o fundamento de professar crença religiosa, dentro de um hospital (público ou privado) possa impedir o médico de cumprir com sua histórica missão de salvar vidas, valendose dos instrumentos, técnicas e tratamentos que a ciência médica lhe proporciona. Mais: se é aceitável que o médico (sobretudo o servidor público) se exponha a ser responsabilizado administrativa, civil e penalmente caso venha a atender à manifestação de vontade do paciente, que recusa tratamento clínico com sua crença religiosa.

Há fundamentos jurídicos sólidos e importantes adotados por parte da doutrina brasileira ${ }^{3}$ e por parte da jurisprudência no sentido de que os médicos devem respeitar a crença professada pelos seguidores da religião Testemunhas de Jeová, merecendo destaque os seguintes argumentos:

direito do cidadão de professar crença religiosa, ainda que as opções por ele externadas, a despeito de seguir o dogma religioso que adota, ponham em risco a sua vida;

direito do cidadão de dispor do próprio corpo, como manifestação do princípio da privacidade;

direito do cidadão de recusar tratamento médico, com fundamento em crença religiosa e também no princípio da autonomia da vontade, o que, à luz da CRFB/88, permite ao cidadão (paciente) o exercício de objeções de consciência;

o princípio da dignidade humana, que exige seja o homem/cidadão concebido não como um instrumento do direito, mas um fim em si mesmo, destinatário dos direitos fundamentais encartados na CRFB/88, entre eles o de professar crença religiosa que impeça a continuidade da vida humana caso alguma medida clínica ou médica contrarie seus fundamentos religiosos.

Com a vênia devida aos que pensam de modo diferente, minha opinião jurídica é contrária aos argumentos supra. Passo a fundamentá-la.

\footnotetext{
${ }^{3}$ De se mencionar, por todos, em apoio à tese contrária que será sustentada neste trabalho e para garantir-se a transparência profissional na informação acadêmica, o profundo estudo, fruto de sua tese de doutorado defendida na Uerj, realizado pelo professor de direito constitucional da PUC-Rio, doutor Fábio Carvalho Leite, intitulado Liberdade de crença e a objeção à transfusão de sangue por motivos religiosos, gentilmente cedido para pesquisa.
} 


\section{Regulação jurídica da transfusão de sangue. Limites da autonomia da vontade do paciente}

Importante registrar que não há norma legal e constitucional que expressamente regule o problema da obrigatoriedade da transfusão de sangue no Brasil.

Importante informar sobre o Projeto de Lei (PL) no 6.335/2009, de autoria do deputado federal Gonzaga Patriota, que se propõe a regulamentar o "direito à objeção de consciência", mas que, em nenhum momento, salvo melhor juízo, discute o dever do médico de não ministrar tratamento clínico a paciente por conta de suas convicções religiosas, sobretudo quando estiver em iminente risco de morte.

O estado do Rio de Janeiro, por meio da Lei Estadual nº 3.613, de 18 de julho de 2001 (que regulamentou o art. 287, da Constituição do Estado do Rio de Janeiro de 1989), dispôs sobre os direitos dos usuários dos serviços de saúde e, no art. 2º inciso VII, ${ }^{4}$ estabeleceu ser direito do usuário ter ciência clara e precisa dos procedimentos e tratamentos a que será submetido, para possibilitar-lhe o consentimento ou a recusa. A regra não inova no ordenamento jurídico, uma vez que repete, conforme será explorado, o que contém no art. 15 do Código Civil brasileiro e em nenhum momento faculta ao cidadão dispor da própria vida, quando em iminente perigo em hospital público, por motivos de ordem religiosa.

Importante registrar que a Lei Estadual no 3.613/2001, de forma bastante polêmica, parece permitir, no art. $2^{\circ}$, inciso XXIII, a prática da distanásia, quando estabelece ser direito do cidadão "recusar tratamentos dolorosos ou extraordinários para tentar prolongar a vida". A distanásia, a meu juízo, se diferencia sobremaneira da questão tratada neste trabalho, na medida em que não se propõe salvar a vida do doente que está em iminente perigo, mas sim o seu mero prolongamento com remédios e terapias dolorosas, que apenas trarão mais sofrimento para o paciente e o farão morrer lentamente. ${ }^{5}$

\footnotetext{
4 "Art. $2^{\mathrm{o}}$ São direitos dos usuários dos serviços de saúde no Estado do Rio de Janeiro: [...] VII - consentir ou recusar, de forma livre, voluntária e esclarecida, com adequada informação, procedimentos diagnósticos ou terapêuticos a serem realizados; [...]."

${ }^{5} \mathrm{O}$ conceito e a compreensão da distanásia são fornecidos pelo ex-procurador do estado do Rio de Janeiro e hoje juiz de direito do Tribunal de Justiça do Estado do Rio de Janeiro, Renato Lima Charnaux Sertã (2005:32): “Fenômeno típico da sociedade atual e decorrente da evolução da medicina, a distanásia ainda não foi bem compreendida, tampouco suficientemente referida e considerada pelos estudiosos ligados à medicina ou ao direito. No sentido vernacular, distanásia significa 'morte lenta, com grande sofrimento'. Em termos médicos, face às circunstâncias de avanço tecnológico antes descritas, o conceito encontra-se hoje ligado, mais do que à própria morte lenta, às suas causas, que protraem de forma dolorosa o momento final da existência. Nesse passo, talvez o conceito mais em voga a respeito da distanásia seja atualmente o de 'tratamento médico fútil', quando ministrado em pacientes portadores de graves moléstias, para as quais não há solução facilmente identificável pela ciência médica".
} 
Enfatize-se, assim, que não há norma legal que permita, expressamente, a objeção ao recebimento de transfusão de sangue com fundamento em crença religiosa.

Todavia, o Conselho Federal de Medicina (CFM) editou a Resolução CFM no 1.021/80 e estabeleceu que os médicos do Brasil, públicos ou privados, devem, em caso de risco de morte do paciente, não sendo possível qualquer outra técnica alternativa, proceder à transfusão de sangue. Confira-se, por sua importância para o caso em análise, a íntegra da referida resolução:

\section{RESOLUÇÃO CFM noㅜ 1.021/80}

O CONSELHO FEDERAL DE MEDICINA, usando da atribuição que lhe confere a Lei $\mathrm{n}^{\mathrm{o}}$ 3.268, de 30 de setembro de 1957, regulamentada pelo Decreto $\mathrm{n}^{\mathrm{o}} 44.045$, de 19 de julho de 1958, e

CONSIDERANDO o disposto no artigo 153, parágrafo $2^{\circ}$ da Constituição Federal; no artigo 146 e seu parágrafo 3ㅜ, incisos I e II do Código Penal; e nos artigos 1ํ, 30 e 49 do Código de Ética Médica;

CONSIDERANDO o caso de paciente que, por motivos diversos, inclusive os de ordem religiosa, recusa a transfusão de sangue;

CONSIDERANDO, finalmente, o decidido em sessão plenária deste Conselho realizada no dia 26 de setembro de 1980,

\section{RESOLVE:}

Adotar os fundamentos do anexo PARECER, como interpretação autêntica dos dispositivos deontológicos referentes à recusa em permitir a transfusão de sangue, em casos de iminente perigo de vida.

Rio de Janeiro, 26 de setembro de 1980.

GUARACIABA QUARESMA GAMA

Presidente em exercício

JOSÉ LUIZ GUIMARÃES SANTOS

Secretário geral

Publicada no DOU (Seção I - Parte II) de 22.10.80

\section{PARECER PROC. CFM nº 21/80}

O problema criado, para o médico, pela recusa dos adeptos da Testemunha de Jeová em permitir a transfusão sanguínea, deverá ser encarado sob duas circunstâncias: 
1. A transfusão de sangue teria precisa indicação e seria a terapêutica mais rápida e segura para a melhora ou cura do paciente.

Não haveria, contudo, qualquer perigo imediato para a vida do paciente se ela deixasse de ser praticada.

Nessas condições, deveria o médico atender o pedido de seu paciente, abstendo-se de realizar a transfusão de sangue.

Não poderá o médico proceder de modo contrário, pois tal lhe é vedado pelo disposto no artigo 32, letra " $\mathrm{f}$ " do Código de Ética Médica:

"Não é permitido ao médico:

f) exercer sua autoridade de maneira a limitar o direito do paciente resolver sobre sua pessoa e seu bem-estar."

2. O paciente se encontra em iminente perigo de vida e a transfusão de sangue é a terapêutica indispensável para salvá-lo.

Em tais condições, não deverá o médico deixar de praticá-la apesar da oposição do paciente ou de seus responsáveis em permiti-la.

O médico deverá sempre orientar sua conduta profissional pelas determinações de seu Código.

No caso, o Código de Ética Médica assim prescreve:

"Artigo 1ํㅗ A medicina é uma profissão que tem por fim cuidar da saúde do homem, sem preocupações de ordem religiosa..."

"Artigo 30. O alvo de toda a atenção do médico é o doente, em benefício do qual deverá agir com o máximo de zelo e melhor de sua capacidade profissional."

"Artigo 19. O médico, salvo o caso de 'iminente perigo de vida', não praticará intervenção cirúrgica sem o prévio consentimento tácito ou explícito do paciente e, tratando-se de menor incapaz, de seu representante legal."

Por outro lado, ao praticar a transfusão de sangue, na circunstância em causa, não estará o médico violando o direito do paciente.

Realmente, a Constituição Federal determina em seu artigo 153, parágrafo $2^{\circ}$ que "ninguém será obrigado a fazer ou deixar de fazer alguma coisa senão em virtude da lei".

Aquele que violar esse direito cairá nas sanções do Código Penal quando este trata dos crimes contra a liberdade pessoal, que em seu artigo 146 preconiza: 
"Constranger alguém, mediante violência ou grave ameaça, ou depois de lhe haver reduzido, por qualquer meio, a capacidade de resistência, a não fazer o que a lei permite, ou a fazer o que ela não manda."

Contudo, o próprio Código Penal, no parágrafo $3^{\circ}$ desse mesmo artigo 146, declara:

"Não se compreendem na disposição deste artigo:

I - a intervenção médica ou cirúrgica sem o consentimento do paciente ou de seu representante legal, se justificada por iminente perigo de vida".

A recusa do paciente em receber a transfusão sanguínea, salvadora de sua vida, poderia, ainda, ser encarada como suicídio. Nesse caso, o médico, ao aplicar a transfusão, não estaria violando a liberdade pessoal, pois o mesmo parágrafo 3ำ do artigo 146, agora no inciso II, dispõe que não se compreende, também, nas determinações deste artigo: "a coação exercida para impedir o suicídio".

\section{CONCLUSÃO}

Em caso de haver recusa em permitir a transfusão de sangue, o médico, obedecendo a seu Código de Ética Médica, deverá observar a seguinte conduta:

$1^{\circ}$ ) Se não houver iminente perigo de vida, o médico respeitará a vontade do paciente ou de seus responsáveis.

$2^{\circ}$ ) Se houver iminente perigo de vida, o médico praticará a transfusão de sangue, independentemente de consentimento do paciente ou de seus responsáveis.

\section{Dr. TELMO REIS FERREIRA}

Relator

O Conselho Regional de Medicina do Estado do Rio de Janeiro - Cremerj, reiterando a normatização traçada pelo CFM, editou a Resolução Cremerj no 136/99 para regular a matéria controvertida objeto deste estudo. Vejamos os arts. $1^{\circ}$ e $3^{\circ}$ :

Art. $1^{\text {o }} \mathrm{O}$ médico, ciente formalmente da recusa do paciente em receber transfusão de sangue e/ou seus derivados, deverá recorrer a todos os métodos alternativos de tratamento ao seu alcance.

Art. 3o O médico, verificando a existência de risco de vida para o paciente, em qualquer circunstância, deverá fazer uso de todos os meios ao seu alcan- 
ce para garantir a saúde do mesmo, inclusive efetuando a transfusão de sangue e/ou seus derivados, comunicando, se necessário, à Autoridade Policial competente sobre sua decisão, caso os recursos utilizados sejam contrários ao desejo do paciente ou de seus familiares.

O Código de Ética Médica, instituído por meio da Resolução CFM nº 1.246/88, de 8 de janeiro de 1988, publicada no DOU de 26 de janeiro do mesmo ano, por sua vez, estabelece:

É vedado ao médico:

Art. 46. Efetuar qualquer procedimento médico sem o esclarecimento e o consentimento prévios do paciente ou de seu responsável legal, salvo em iminente perigo de vida.

Art. 56. Desrespeitar o direito do paciente de decidir livremente sobre a execução de práticas diagnósticas ou terapêuticas, salvo em caso de iminente perigo de vida.

Art. 57. Deixar de utilizar todos os meios disponíveis de diagnósticos e tratamento a seu alcance em favor do paciente.

Percebe-se, pois, que à luz da regulação técnica transcrita supra, que a entidade competente para regular a atuação médica, inclusive o seu atuar ético, obriga o médico a proceder ao tratamento clínico - inclusive transfusão de sangue - necessário para salvar a vida do paciente.

Necessário advertir que os conselhos federal e regional de medicina, a exemplo de outros conselhos profissionais, têm previsão constitucional (arts. $5^{\circ}$, incisos XIII, ${ }^{6}$ 21, XXIV7 e 22, XVI, ${ }^{8}$ todos da CRFB/88), e exercem, na qualidade de autarquias, o poder disciplinar quanto às suas atividades e sobre seus profissionais. ${ }^{9}$

\footnotetext{
6 "Art. 50: Todos são iguais perante a lei, sem distinção de qualquer natureza, garantindo-se aos brasileiros e aos estrangeiros residentes no País a inviolabilidade do direito à vida, à liberdade, à igualdade, à segurança e à propriedade, nos termos seguintes: [...] XIII - é livre o exercício de qualquer trabalho, ofício ou profissão, atendidas as qualificações profissionais que a lei estabelecer; (....."

7 "Art. 21. Compete à União: [...] XXIV - organizar, manter e executar a inspeção do trabalho; [...]."

8 "Art. 22. Compete privativamente à União legislar sobre: [...] XVI - organização do sistema nacional de emprego e condições para o exercício de profissões; [...]."

${ }^{9}$ Sobre a qualificação dos conselhos profissionais como autarquias federais, colham-se as lições do procurador da República, dr. Ronaldo Pinheiro de Queiroz: "Diante disso, a partir da constatação da natureza jurídica de autarquia federal dos conselhos federais, e tomando-a como premissa primária, as consequências jurídicas daí decorrentes ficam afetas ao regime jurídico administrativo, trazendo para os conselhos as mesmas prerrogativas e restrições da administração pública indireta.

Daí em diante, pode-se concluir que esses entes têm as mesmas vantagens e privilégios da administração, mas também têm os mesmos ônus, devendo realizar concurso público para admissão de seu
} 
Por isso ouso ponderar que o poder normativo e regulador dos conselhos federal e regional de medicina emerge da CRFB/88.

A reforçar a posição adotada pelo Conselho Federal de Medicina e pelo Conselho Regional de Medicina do Estado do Rio de Janeiro, que obrigam o médico a proceder à transfusão de sangue em pacientes que estejam em risco de morte, pode-se citar a regra contida no artigo 15 do Código Civil, assim redigida: "Art. 15. Ninguém pode ser constrangido a submeter-se, com risco de vida, a tratamento médico ou a intervenção cirúrgica".

Ora, conforme se extrai da leitura do mencionado dispositivo legal, o Código Civil, editado em 2002, conferiu efetividade ao "princípio da autonomia da vontade do paciente", permitindo que participe das decisões que digam respeito aos tratamentos que lhe serão ministrados, junto com o médico, estabelecendo claramente o limite de tal conjugação de decisões: até o momento em que a vida do paciente não correr perigo de fenecer. Nessa hipótese, penso, o legislador civil de 2002, em franca interpretação da Constituição Federal de 1988, estabeleceu que, em havendo perigo de morte do paciente, o médico, conhecedor de estudos técnicos, deve sempre atuar para impedir que tal aconteça, cabendo a ele decidir sobre as técnicas médicas disponíveis, independentemente de crenças religiosas, inclusive por parte dos médicos.

Necessário ainda registrar que o Código Civil de 2002, em franca "interpretação autêntica"10 da CRFB/88, trouxe ao ordenamento jurídico duas regras de conduta sobre a "autonomia da vontade" e "os direitos da personalidade", como sói ser a vida humana, que merecem ser destacadas neste trabalho:

aduz serem os direitos da personalidade intransmissíveis e irrenunciáveis, e que não podem sofrer limitação voluntária;

pessoal, seguir as regras do regime jurídico do pessoal que estabelecer, realizar licitação, entre outros consectários desse regime de caráter público.

Os conselhos que ainda se portam como entidades privadas deverão se adequar estrutural e funcionalmente para usar a roupagem de autarquia federal, a fim de não perderem a legitimidade de seus atos, pois, se não se conduzirem dessa forma, estarão desrespeitando a própria Constituição" (Queiroz, Ronaldo Pinheiro de. A natureza jurídica dos conselhos fiscais de profissões regulamentadas. Jus $\mathrm{Na}$ vigandi, Teresina, ano 10, n. 1211, 25 out. 2006. Disponível em: <http://jus2.uol.com.br/doutrina/texto. asp?id=9082>. Acesso em: 12 jan. 2010).

${ }^{10}$ A expressão "interpretação autêntica" não tem sido empregada em consonância técnica com a melhor doutrina do direito constitucional, mas pretende expressar a interpretação da Constituição da República pelo Poder Legislativo. Nada obstante, confira-se, na lição de Luís Roberto Barroso (2002:118-119), a correta conceituação do fenômeno da "interpretação constitucional autêntica": "É controvertida a possibilidade de interpretação autêntica da Constituição. Aliás, é controvertida a própria existência da categoria interpretação autêntica, como tal entendida a que emana do próprio órgão que elaborou o ato cujo sentido e alcance ela declara. Pela interpretação autêntica se edita uma norma interpretativa de outra preexistente. A maior parte da doutrina, tanto brasileira como portuguesa, admite a interpretação constitucional autêntica, desde que se faça pelo órgão competente para a reforma constitucional, com observância do mesmo procedimento desta". 
que é vedado ao ser humano a disposição do próprio corpo, inclusive quando importar em permanente diminuição da integridade física.

Vejamos, a propósito, as dicções dos arts. 11 e 13 do referido Código Civil:

Art. 11. Com exceção dos casos previstos em lei, os direitos da personalidade são intransmissíveis e irrenunciáveis, não podendo o seu exercício sofrer limitação voluntária.

Art. 13. Salvo por exigência médica, é defeso o ato de disposição do próprio corpo, quando importar diminuição permanente da integridade física, ou contrariar os bons costumes.

Parágrafo único. $\mathrm{O}$ ato previsto neste artigo será admitido para fins de transplante, na forma estabelecida em lei especial.

Consoante as regras transcritas supra, parece que há normas jurídicas vigentes que impedem a "objeção de consciência" por parte de pessoas que se dizem seguidoras da seita Testemunhas de Jeová para recusarem transfusão de sangue e, assim, disporem do próprio corpo e também do maior direito da personalidade tutelado pela Constituição da República de 1988, qual seja, a vida.

Isto não quer dizer, porém, que os médicos não devam buscar, o quanto possível, as técnicas médicas que não contrariem as crenças religiosas dos pacientes. Devem fazê-lo até o limite em que não se verificar a encruzilhada que responde à indagação: o tratamento contrário à vontade do paciente ou a morte? Nessa hipótese, penso, deve decidir pelo tratamento contrário à vontade do paciente para preservar o maior e primordial direito fundamental tutelado pela Constituição da República de 1988, qual seja, a vida humana. Essa, ao que parece, é a posição de Carlos Emmanuel Ragazzo (2007:114), que, ao escrever sobre o problema objeto deste trabalho, aduz:

No Brasil, a doutrina entende que a recusa deve ser respeitada, desde que não haja risco de vida. A letra do art. 15 do Código Civil vem permitindo essa interpretação, o que, aliás, já era uma posição jurisprudencial mesmo antes da promulgação do novo diploma cível. A prevalência do direito à vida, considerado como verdadeiramente indisponível, sobre o direito de autodeterminação constitui o fundamento das decisões judiciais que permitem a intervenção médica quando há risco iminente de vida. 
Assim, a meu juízo, os arts. 11, 13 e 15, todos do Código Civil, e as regras técnicas dos conselhos Federal e Regional de Medicina do estado do Rio de Janeiro e, ainda, o Código de Ética Médica, conferiram efetividade ao maior direito fundamental protegido pela Constituição da República de 1988, cuja defesa incessante e intransigente compete ao Estado, isto é, a vida humana, sem a qual (e/ou contra ela) não há razão jurídica para se pleitear o exercício de qualquer outro direito fundamental, inclusive a liberdade religiosa.

\section{Direito à vida. Necessidade do Estado de garantir a vida humana. Concepção dos direitos fundamentais. Ponderação de valores}

O direito fundamental à vida e à saúde está previsto na Constituição da República de 1988 nos arts. 5ํ e 6º , que estão assim redigidos:

Art. 5o Todos são iguais perante a lei, sem distinção de qualquer natureza, garantindo-se aos brasileiros e aos estrangeiros residentes no País a inviolabilidade do direito à vida, à liberdade, à igualdade, à segurança e à propriedade, nos termos seguintes:

$[\ldots]$

Art. $6^{0}$ São direitos sociais a educação, a saúde, o trabalho, a moradia, o lazer, a segurança, a previdência social, a proteção à maternidade e à infância, a assistência aos desamparados, na forma desta Constituição.

Conforme se percebe, por expressa disposição constitucional a vida e a saúde são direitos fundamentais e sociais invioláveis do cidadão e, nos termos do art. 196 da CRFB/88, é dever do Estado protegê-los:

Art. 196. A saúde é direito de todos e dever do Estado, garantido mediante políticas sociais e econômicas que visem à redução do risco de doença e de outros agravos e ao acesso universal e igualitário às ações e serviços para sua promoção, proteção e recuperação.

Se assim é, e efetivamente o é, a partir da vida e do seu inafastável corolário - existência humana - é que surgirão e que serão interpretados todos os outros direitos fundamentais previstos na $\mathrm{CRFB} / 88$, entre eles o direito à autonomia da vontade para professar crenças religiosas.

Em abono à tese sustentada neste trabalho, confira-se a doutrina de Alexandre de Moraes (2004:65-66): 
A Constituição Federal garante que todos são iguais perante a lei, sem distinção de qualquer natureza, garantindo-se aos brasileiros e aos estrangeiros residentes no País a inviolabilidade do direito à vida, à liberdade, à igualdade, à segurança e à propriedade. O Direito à vida é o mais fundamental de todos os direitos, já que se constitui em pré-requisito à existência de todos os demais direitos.

A Constituição Federal proclama, portanto, o direito à vida, cabendo ao Estado assegurá-lo em sua dupla acepção, sendo a primeira relacionada ao direito de continuar vivo e a segunda de se ter vida digna quanto à subsistência.

No mesmo sentido, colham-se as sempre autorizadas lições de José Afonso da Silva (1998:200-201):

Todo ser dotado de vida é indivíduo, isto é: algo que não se pode dividir, sob pena de deixar de ser. O homem é um indivíduo, mas é mais que isto, é uma pessoa. (...) A vida humana, que é objeto do direito assegurado no art. 5oㅡ. caput, integra-se de elementos materiais (físicos e psíquicos) e imateriais (espirituais). [...]. Por isso é que ela constitui a fonte primária de todos os outros bens jurídicos. De nada adiantaria a Constituição assegurar outros direitos fundamentais, como a igualdade, a intimidade, a liberdade, o bem-estar, se não erigisse a vida humana num desses direitos. No conteúdo de seu conceito se envolvem o direito à dignidade da pessoa humana (de que já tratamos), o direito à privacidade (de que cuidaremos no capítulo seguinte), o direito à integridade físico-corporal, o direito à integridade moral e, especial, o direito à existência. (Itálico do original, grifos nossos)

A propósito do "princípio da existência" como corolário da vida humana, bem assim sua aplicação a situações similares à vertida nesse processo, prossegue José Afonso da Silva (1998:201-202):

Consiste (o direito à existência) no direito de estar vivo, de lutar pelo viver, de defender a própria vida, de permanecer vivo. É o direito de não ter interrompido o processo vital senão pela morte espontânea e inevitável. Existir é o movimento espontâneo contra o estado morte. Porque se assegura o direito à vida é que a legislação penal pune todas as formas de interrupção violenta do processo vital. É também por essa razão que se considera legítima a defesa contra qualquer agressão à vida, bem como se reputa legítimo até mesmo tirar a vida a outrem em estado de necessidade de salvação da própria.

Tentou-se incluir na Constituição o direito a uma existência digna. Esse conceito de existência digna consubstancia aspectos generosos de natureza material e moral; 
serviria para fundamentar o desligamento de equipamentos médicos-hospitalares, nos casos em que o paciente estivesse vivendo artificialmente (mecanicamente), a prática da eutanásia, mas trazia implícito algum risco como, por exemplo, autorizar a eliminação de alguém portador de deficiência de tal monta que se viesse a concluir que não teria existência humana digna. Por esses riscos, talvez tenha sido melhor não acolher o conceito.

Outro não é o entendimento do jurista francês Jacques Robert:

O respeito à vida humana é a um tempo uma das maiores ideias de nossa civilização e o primeiro princípio da moral médica. É nele que repousa a condenação do aborto, do erro ou da imprudência terapêutica, a não aceitação do suicídio. Ninguém terá o direito de dispor da própria vida, a fortiori da de outrem e, até o presente, o feto é considerado como um ser humano. ${ }^{11}$

Devo argumentar, de outro lado, que o direito fundamental à vida humana deve ser considerado um "direito universal" quase que absoluto, não podendo ser "relativizado e/ou flexibilizado" para atender a culturas regionais religiosas e/ ou fundamentalistas. Creio que o conceito de direitos fundamentais cunhado por estudos produzidos no ocidente, sobretudo para combater as visões do conceito à luz da "teoria do relativismo cultural", não autoriza o discurso utilizado para garantir um direito fundamental extremado por uma interpretação religiosa e/ou cultural em detrimento da vida humana. Isto é, à luz da doutrina "universalista dos direitos humanos", não é possível que cada cultura - "ou ramo dela, tal qual uma religião" - tenha liberdade para estabelecer tratamentos prioritários aos direitos fundamentais, segundo suas convicções, crenças e doutrinas. Confira-se, a propósito da discussão referida supra, a doutrina de Flávia Piovesan (2004:58-62):

Para os relativistas, a noção de direitos está estritamente relacionada ao sistema político, econômico, cultural, social e moral vigente em determinada sociedade. Neste prisma, cada cultura possui seu próprio discurso acerca dos direitos fundamentais, que está relacionado às específicas circunstâncias culturais e históricas de cada sociedade. Nesse sentido, acreditam os relativistas, o pluralismo cultural impede a formação de uma moral universal, tornando-se necessário que se respeite as diferenças culturais apresentadas por cada sociedade, bem como seu peculiar sistema moral. A título de exemplo, bastaria citar as diferenças de padrões morais e culturais entre o islamismo e o hinduísmo e o mundo ocidental, no que tange ao movimento de direitos humanos.

\footnotetext{
${ }^{11}$ Robert (1971) apud Silva (1998), p. 201.
} 
Como ilustração, caberia mencionar a adoção da prática de clitorectomia e mutilação feminina por muitas sociedades da cultura não ocidental.

Na percepção de Jack Donelly: "Nós não podemos passivamente assistir a atos de tortura, desaparecimento, detenção e prisão arbitrária, racismo, antissemitismo, repressão a sindicatos e igrejas, miséria, analfabetismo, doenças, em nome da diversidade ou respeito a tradições culturais. Nenhuma dessas práticas merece o nosso respeito, ainda que seja considerada tradição" (Universal rights in theory and practice, Ithaca, Cornell University Press, 1989, p. 235).

Nas lições de R.J. Vincent: “O que a doutrina do relativismo cultural pretende? Primeiramente, ela sustenta que as regras sobre a moral variam de lugar para lugar. Em segundo lugar, ela afirma que a forma de compreensão dessa diversidade é colocar-se no contexto cultural em que ela se apresenta. E, em terceiro lugar, ela observa que as reivindicações morais derivam de um contexto cultural, que em si mesmo é a fonte de sua validade. Não há moral universal, já que a história do mundo é a história de uma pluralidade de culturas e, nesse sentido, buscar uma universalidade, ou até mesmo o princípio de universalidade clamado por Kant, como critério para toda a moralidade, é uma versão imperialista de tentar fazer com que valores de uma determinada cultura sejam gerais. [...] Há uma pluralidade de culturas no mundo e essas culturas produzem seus próprios valores". Na visão da Jack Donelly, há diversas correntes relativistas: "No extremo, há o que nós denominamos de relativismo cultural radical, que concebe a cultura como a única fonte de validade de um direito ou regra moral. [...] Um forte relativismo cultural acredita que a cultura é a principal fonte de validade de um direito ou regra moral. [...] Um relativismo cultural fraco, por sua vez, sustenta que a cultura pode ser importante fonte de validade de um direito ou regra moral".

Note-se que os instrumentos internacionais de direitos humanos são claramente universalistas, uma vez que buscam assegurar a proteção universal dos direitos e liberdades fundamentais. Daí a noção de expressões como: "todas as pessoas" (ex.: "todas as pessoas têm direito à vida e à liberdade" - art. $2^{\underline{o}}$ da Declaração), "ninguém" (ex.: "ninguém poderá ser submetido à tortura" - art. $5^{\text {o }}$ da Declaração), entre outras. Em face disso, ainda que o direito a exercer a própria cultura seja um direito fundamental (inclusive previsto na Declaração Universal), nenhuma concessão é feita às "peculiaridades culturais", quando há risco de violação a direitos humanos fundamentais. ${ }^{12}$ (Grifos nossos)

\footnotetext{
${ }^{12}$ Apenas para registro, consta, na mesma obra de Flávia Piovesan (2004:314), trabalho produzido pela presidente da International Movement for a Jus World (JUST), na Malásia, e senior fellow da Universida-
} 
Ademais, apesar de as doutrinas modernas não estabelecerem um conceito apriorístico e determinado do que seja a "dignidade humana" como valor a guiar a aplicação e interpretação dos direitos fundamentais, mas estabelecerem que no referido conceito está, certamente, a possibilidade de o cidadão ser responsável pelos destinos da sua existência e vida, ${ }^{13}$ creio que tal concepção não pode ser levada ao extremo, sobretudo em um país como o Brasil, dotado de quantidade imensa de seitas e religiões, com fundamentos dos mais diversos, para permitir que pessoas, muitas das vezes influenciadas por pregações alheias, mas sem profunda convicção de sua real crença e de suas verdades, atentem contra a própria vida. Por outro lado, não posso deixar de reafirmar que o corolário maior da dignidade humana é a vida, sem a qual, repita-se, não há falar-se ou justificar-se o exercício de nenhum outro direito para conferir dignidade a um cidadão; até porque se o destinatário da proteção estiver morto, não será possível pretender proteger a dignidade humana.

Na esteira do que se sustenta supra, penso ser oportuna a transcrição da doutrina dos professores da Universidade Federal de Juiz de Fora Rodrigo Iennaco de Moraes e Rodrigo Esteves Santos Pires, em artigo intitulado "Transfusão de sangue em pacientes Testemunhas de Jeová: religião, ética e discurso jurídico-penal”:

Filiamo-nos à corrente dos que veem, como pressuposto do princípio da dignidade da pessoa humana, a intangibilidade da vida. Estabelecida essa premissa, a ocorrência de iminente perigo de vida se traduz em autorização constitucional para que o médico, independentemente da vontade do paciente (ou de quem o represente), realize a transfusão, quando cientificamente, observada a lex arte, revele-se como o único meio apto a salvar a vida em iminente perigo de perecimento.

Liberdade e vida são bens jurídicos positivados constitucionalmente em nível fundamental. Porém, não se lhes empresta, num raciocínio jusnaturalista, a mesma envergadura. Isso se dá porque, embora se reconheça que sem liberdade pode não haver vida digna, sem vida não faz sentido falar-se em liberdade e não há razão para se discutir dignidade. A vida tem valor absoluto, numa escala de valores que precede a positivação ou o reconhecimento jurídico de tutela de quaisquer outros bens ou interesses.

de da Malásia, dra. Chandra Muzaffar, criticando ferozmente o conceito de direitos humanos cunhado pela doutrina ocidental, de modo a impô-lo às demais comunidades do mundo. Destaco, porém, que o principal direito da humanidade é a vida. Confira-se: "Mais do que qualquer direito político, civil, social, cultural ou econômico, a vida é considerada pelo islã como sendo direito supremo. A vida humana, observa a Declaração Universal Islâmica, 'é sagrada e inviolável' e não se devem medir esforços para protegê-la".

${ }^{13}$ Nesse sentido, manifesta-se a doutrina de Ingo Wolfgang Sarlet (2001:38-40 e 60). 


\section{$[\ldots]$}

Como dito, sem vida não há dignidade, nem liberdade, nem convicção, nada. E se a vida é valor absoluto, toda e qualquer conduta tendente a sua preservação encontra, iniludivelmente, esteio constitucional.

\section{$[\ldots]$}

E sem que isso implique a negação da própria liberdade de opção pela morte. Não. Implicará, sim, o reconhecimento constitucional de outro viés da própria liberdade, qual seja, o seu e o nosso direito de intervenção, sempre que possível, em favor da vida, de sua preservação, de sua intangibilidade. Se alguém resolve se matar por convicção religiosa, utilizando-se de qualquer meio, que o faça por seus próprios meios e fora da esfera de intervenção daqueles que, também por convicção religiosa, por dever legalmente previsto, ou simplesmente por amor à vida, não se podem curvar passivamente diante de uma vida que, com a utilização dos meios terapêuticos disponíveis (e, frise-se, quando os meios aceitos pelo paciente não se mostrarem eficazes), provavelmente não se ceifaria.

É a dignidade da pessoa humana - que tem na existência da vida seu pressuposto inafastável - o valor fundante de toda e qualquer interpretação constitucional dos direitos fundamentais. A dignidade da vida pressupõe a vida. Somente em atenção à vida e enquanto ela durar fará sentido a positivação da tutela de sua dignidade. ${ }^{14}$

Reforça-se, com isso, a tese de que em juízo de "ponderação de valores"15 entre o exercício momentâneo de uma crença religiosa que exponha a risco o direito à vida (e de existência) do cidadão e o dever do Estado de, por meio de seus profissionais de saúde (ou mesmo de médicos privados), garantir a inviolabilidade do direito à vida (e da existência humana, como expressão maior do princípio da dignidade da pessoa humana), deve, a meu sentir, por força do disposto nos arts. 5º, caput, e 196, ambos da CRFB/88, atuar em defesa da vida e da existência

\footnotetext{
${ }^{14}$ Rodrigo Iennaco de Moraes e Rodrigo Esteves Santos Pires. Transfusão de sangue em pacientes testemunhas de Jeová: religião, ética e discurso jurídico-penal (partes 1 e 2). Disponível em: <http://www.direitopenalvirtual.com.br/artigos/leiamais/default.asp?id=13> e <http:/www.direitopenalvirtual.com. br/artigos/leiamais/default.asp?id=14>. Publicado em: 13 dez. 2006. Acesso em: 12 jan. 2010.

${ }^{15}$ A propósito, confira-se a doutrina de Daniel Sarmento (2000:102): “Vencida a etapa acima referida, defronta-se o intérprete com a constatação de que determinada hipótese é, de fato, tutelada por dois princípios constitucionais, que apontam para soluções divergentes.

Neste caso, ele deve, à luz das circunstâncias concretas, impor 'compensações' recíprocas sobre os interesses protegidos pelos princípios em disputa, objetivando lograr um ponto ótimo, onde a restrição a cada interesse seja a mínima indispensável à sua convivência com o outro".
} 
humana (valor fundamental universal), até porque a inação do médico, agente do estado ou não, pode representar, para ele, severas punições administrativas, cíveis e criminais.

Creio que a liberdade de religião e a laicidade do Estado não podem impedir o Poder Público de agir em defesa da vida humana ao ter ciência de que pessoas estão colocando em risco suas próprias vidas - "por fundamento religioso" - e podem vir a atingir a esfera jurídica de terceiros (no caso deste trabalho, a dos médicos, que terminam por ficar em posição de vulnerabilidade caso deixem de atuar). Tenho que a proteção de um direito fundamental (liberdade de crença e religião) não pode esvaziar, por completo, o exercício de outro dever constitucional imposto, sobretudo ao Estado, que é o de garantir a preservação da vida humana.

Como exemplo, penso que é dever do Estado tentar impedir o suicídio de pessoa que sobe no alto de um prédio público e ameace de lá se projetar para o chão, com o argumento de que pecou contra sua doutrina religiosa. Mais: creio não poderá o Estado permanecer indiferente à certeza de que alguém está se mutilando ou se flagelando em ritual religioso, sob o fundamento de que há de se respeitar a liberdade de crença e do exercício dos dogmas da fé. Também não é possível obstar o Estado de atuar contra determinada religião que, a despeito de interpretar escritos históricos religiosos, professa como pena o enforcamento de cidadão que vier a contrariar um de seus dogmas, incitando-os, verdadeiramente.

Sem dúvida, são situações difíceis que se apresentam no liame entre a liberdade de crença e a possibilidade de intervenção estatal decorrente de sua laicidade. A mim me parece que a liberdade religiosa e o desenvolvimento de seus fundamentos devem ser exercidos de modo "razoável e proporcional", sobretudo para não sacrificar o maior bem jurídico, tido por fundamental e inviolável, e, por isso, protegido constitucionalmente, que é a vida e a existência humana. Do contrário, penso que a intervenção estatal se faz necessária, até mesmo como medida de "garantia da ordem pública". Nesse sentido, sobretudo com fundamento nos princípios constitucionais da razoabilidade e proporcionalidade, colha-se decisão proferida pelo Tribunal Regional Federal da $4^{\underline{a}}$ Região:

DIREITO À VIDA. TRANSFUSÃO DE SANGUE. TESTEMUNHAS DE JEOVÁ. DENUNCIAÇÃO DA LIDE INDEFERIDA. LEGITIMIDADE PASSIVA DA UNIÃO. LIBERDADE DE CRENÇA RELIGIOSA E DIREITO À VIDA. IMPOSSIBILIDADE DE RECUSA DE TRATAMENTO MÉDICO QUANDO HÁ RISCO DE VIDA DE MENOR. VONTADE DOS PAIS SUBSTITUÍDA PELA MANIFESTAÇÃO JUDICIAL. O recurso de agravo deve ser improvido porquanto à denunciação da lide se presta para a possibilidade de ação regressiva e, no caso, o que se verifica é a responsabilidade solidária dos entes federais, em face da competência comum estabelecida no art. 23 da 
Constituição Federal nas ações de saúde. A legitimidade passiva da União é indiscutível diante do art. 196 da Carta Constitucional. O fato de a autora ter omitido que a necessidade da medicação se deu em face da recusa à transfusão de sangue, não afasta que esta seja a causa de pedir, principalmente se foi também o fundamento da defesa das partes requeridas. A prova produzida demonstrou que a medicação cujo fornecimento foi requerido não constitui o meio mais eficaz da proteção do direito à vida da requerida, menor hoje constando com dez anos de idade. Conflito no caso concreto dois princípios fundamentais consagrados em nosso ordenamento jurídicoconstitucional: de um lado, o direito à vida e de outro, a liberdade de crença religiosa. A liberdade de crença abrange não apenas a liberdade de cultos, mas também a possibilidade de o indivíduo orientar-se segundo posições religiosas estabelecidas. No caso concreto, a menor autora não detém capacidade civil para expressar sua vontade. A menor não possui consciência suficiente das implicações e da gravidade da situação para decidir conforme sua vontade. Esta é substituída pela de seus pais que recusam o tratamento consistente em transfusões de sangue. Os pais podem ter sua vontade substituída em prol de interesses maiores, principalmente em se tratando do próprio direito à vida. A restrição à liberdade de crença religiosa encontra amparo no princípio da proporcionalidade, porquanto ela é adequada à preservar a saúde da autora: é necessária porque em face do risco de vida, a transfusão de sangue torna-se exigível e, por fim, ponderando-se entre vida e liberdade de crença, pesa mais o direito à vida, principalmente em se tratando da vida de filha menor impúbere. Em consequência, somente se admite a prescrição de medicamentos alternativos enquanto não houver urgência ou real perigo de morte. Logo, tendo em vista o pedido formulado na inicial, limitado ao fornecimento de medicamentos, e o princípio da congruência, deve a ação ser julgada improcedente. Contudo, ressalva-se o ponto de vista ora exposto, no que tange ao direito à vida da menor (AC 200371020001556, 3 $3^{\text {a }}$ Turma do TRF-4, relatora desembargadora federal Vânia Hack de Almeida, DJ de 1-11-2006, p. 686).

Ainda sobre o dever de respeito do conteúdo e alcance da liberdade de religião, da laicidade do Estado e do exercício das convicções religiosas por um cidadão, desde que de forma razoável, colham-se as lições pertinentes do constitucionalista português Jorge Miranda (1998:359):

A liberdade religiosa não consiste apenas em o Estado a ninguém impor qualquer religião ou a ninguém impedir de professar determinada crença. Consiste ainda, por um lado, em o Estado permitir ou propiciar a quem seguir determinada religião o cumprimento dos deveres que dela decorrem (em 
matéria de culto, de família ou de ensino, por exemplo) em termos razoáveis. E consiste, por outro lado (e sem que haja qualquer contradição), em o Estado não impor ou não garantir com as leis o cumprimento desses deveres. (Grifos nossos)

Com efeito, e com a licença devida dos que pensam em sentido contrário, penso que não é razoável, à luz dos arts. 5oc caput, e 196, ambos da CRFB/88, que uma pessoa se dirija a um hospital público (ou privado) para receber tratamento médico, isto é, para buscar cura ao mal que lhe aflige e, sob os argumentos de privacidade, autonomia da vontade e objeção de crença religiosa, imponha o não agir a um médico, impedindo-o de cumprir com sua missão maior que é a de salvar vidas valendo-se das técnicas médicas disponíveis, bem assim expondo-o à sorte de experimentar consequências civis (com ações indenizatórias elou ações regressivas do poder público caso seja o Estado condenado pela omissão médica), ${ }^{16}$ administrativas perante o Conselho de Medicina respectivo e também perante as comissões disciplinares do Poder Público a que estiver vinculado, na hipótese de médicos servidores públicos, e penais, ${ }^{17}$ caso se entenda presente delitos penais, tal como omissão de socorro. O meio empregado para conferir, eventualmente, efetividade ao direito fundamental à liberdade de crença religiosa sacrifica o bem jurídico maior tutelado pela CRFB/88, que é a vida. A opção do seguidor da religião Testemunhas

\footnotetext{
${ }^{16}$ Devo registrar que entendo não existir responsabilidade civil do Estado na hipótese de o médico, agente público, não considerar a decisão do seguidor da religião Testemunhas de Jeová e, para salvar sua vida, impor-lhe a transfusão de sangue. Em primeiro lugar, porque a conduta do médico não é ilícita, nos termos da fundamentação apresentada neste trabalho, estando, inclusive, autorizada pelo Código Penal. Ademais, o médico estaria agindo no exercício regular de sua profissão e de um direito, fazendo, por isso, incidir a regra do art. 188, I, do Código Civil. E, por fim, não há falar-se, a meu sentir, em dever de indenizar do Estado por ato lícito, uma vez que tal hipótese é admitida de forma excepcional pela doutrina, somente na hipótese de o ato, nada obstante em conformidade com a Constituição e com as leis, importar para uma pessoa e/ou para um grupo de pessoas sacrifício manifestamente irrazoável e desproporcional de direitos.

${ }^{17}$ A propósito de possíveis efeitos penais ao médico que se omitir no dever de proceder à transfusão de sangue em pessoas que estejam correndo iminente perigo de morte, necessário informar que o STJ, quando do julgamento do RHC 199800517561, entendeu existir justa causa para o recebimento da denúncia. Vejamos: "PROCESSUAL PENAL. HABEAS CORPUS. AÇÃO PENAL. TRANCAMENTO. FALTA DE JUSTA CAUSA. 1. A justa causa, apta a impor o trancamento da ação penal, é aquela perceptível ictu oculi, onde a ilegalidade é patente e evidenciada pela simples enunciação dos fatos a demonstrar ausência de qualquer elemento indiciário que dê base à acusação. 2. Impossível a verificação da existência ou não de crime na via estreita do habeas corpus em razão da necessidade de análise aprofundada de provas. 3. RHC improvido.

INDEXAÇÃO: DESCABIMENTO, TRANCAMENTO DE AÇÃO PENAL, HOMICÍDIO, RÉU, MÉDICO, TESTEMUNHA DE JEOVÁ, RESPONSABILIDADE, IMPEDIMENTO, TRANSFUSÃO DE SANGUE, HIPÓTESE, DENÚNCIA, DESCRIÇÃO, CRIME EM TESE, INEXISTÊNCIA, PROVA INEQUÍVOCA, ATIPICIDADE, CONDUTA, FALTA DE JUSTA CAUSA, NECESSIDADE, DILAÇÃO PROBATÓRIA" (RHC - Recurso ordinário em habeas corpus - 7.785, 6 a Turma do STJ, rel. min. Fernando Gonçalves. DJ de 30-11-1998, p. 00209, RTJE vol.: 00169, p. 00285).
} 
de Jeová viola, assim, o princípio da razoabilidade, na vertente dos subprincípios da necessidade e proporcionalidade em sentido estrito. ${ }^{18}$

Não fossem os argumentos supra suficientes para, em minha modesta opinião, em juízo de ponderação de interesses e/ou de valores, afastar o exercício do direito à crença religiosa e o direito à autonomia da vontade diante do valor universal do direito à vida, cujo dever de proteção é do Estado, cabe trazer à colação estudo realizado por Maria Helena Diniz, que, após discutir acerca dos bens jurídicos que devem prevalecer na hipótese de recusa de transfusão de sangue por pessoas seguidoras da religião Testemunhas de Jeová, se posicionou favoravelmente à intervenção médica forçada, com o intuito de salvaguardar o bem jurídico vida, que, em sua opinião, não possui dimensão unicamente singular, mas sim coletiva, uma vez que sua existência e preservação importam consequências em várias pessoas que estão ao seu redor. Confira-se a lição da referida jurista (Diniz, 2001:213):

Sendo urgentes e inadiáveis o tratamento médico, a intervenção cirúrgica e a transfusão de sangue não consentida, prevalecem diante da ciência, do valor da vida do paciente e do interesse da comunidade, pois a vida é um bem coletivo, que interessa mais à sociedade do que ao indivíduo. Não se pode, portanto, submeter o médico à vontade do doente ou à de seus familiares, porque isso equivaleria a transformá-lo num simples locador de serviços. Acreditamos que o médico, por seu sentido ético e consciência profissional, deve até mesmo correr o risco pessoal imposto por certas circunstâncias, porque sua profissão é a de socorrer pessoas, resguardando-lhes a vida e a saúde. Sua missão é proteger a saúde, logo, seus conhecimentos e sua consciência voltam-se para o cumprimento dessa tarefa (Declaração de Helsinque). A questão da saúde tem natureza ético-política por referir-se à opção entre o respeito ou o desrespeito pelo ser humano.

O Conselho Regional de Medicina de São Paulo, em 1974, deliberou que: a) se paciente grave, inconsciente e desacompanhado de familiares precisar de transfusão de sangue, ela deve ser feita sem demora; b) se paciente grave, inconsciente e acompanhado de parente que impeça a transfusão, o médico

\footnotetext{
${ }^{18}$ A razoabilidade tem sido entendida como decorrência do princípio do devido processo legal, conforme pontificou o próprio Supremo Tribunal Federal (ADIns 855-2 e 1158-8). Pela noção de razoabilidade deve o agente público pautar sua conduta em padrões aceitáveis do ponto de vista da lógica do razoável, atentando-se para três requisitos: (i) adequação - em que se analisa a aptidão dos meios empregados para atingir as finalidades desejadas pelo administrador público; isto é, a medida tomada tem de ser adequada para atingir a finalidade perquirida; (ii) necessidade - por esse requisito analisa-se se, entre os diversos atos possíveis para atingir a finalidade, o que foi escolhido pelo administrador público é o menos gravoso para atendimento dos fins visados; e (iii) proporcionalidade em sentido estrito - a partir desse requisito analisa-se se a conduta administrativa impõe à sociedade, à luz do estado de coisas vigentes antes de sua adoção, ônus equivalente ao benefício a que se visa proporcionar.
} 
deve esclarecê-lo de sua necessidade e, havendo relutância, recorrer à autoridade policial e judicial; e, c) se paciente lúcido se negar à transfusão, deve assinar termo de responsabilidade perante autoridade policial ou judicial, e o médico deve tentar tratamento alternativo.

Todavia, cremos que o médico não precisa de autorização policial ou judicial para efetuar a transfusão de sangue, mesmo não autorizada pelo paciente ou familiares, diante de um iminente perigo de vida, por ser seu dever legal salvar vidas humanas, porque isso o levaria a uma espera, que poderia ocasionar prática do crime de omissão de socorro (CP, art. 135; Código de Ética Médica, arts. 1, 2, 6, 7, 16, 35 e 57). A missão do médico é minimizar o sofrimento humano e resguardar a vida e a saúde, bens supremos da pessoa, sujeitando-se à tutela estatal, pois a Constituição, em seu art. 196, consagra a saúde como direito de todos e dever do Estado. Deveras, Leonídio Ribeiro (citado por Hermes Rodrigues Alcântara, in Deontologia e dicologia, São Paulo, Ed. Andrei, 1979) pondera: “a única profissão que confere aos que exercem o direito de decidir sobre os destinos de uma vida humana em perigo é a medicina, por isso mesmo, os textos das leis penais e os dispositivos dos Códigos de Éticas são muito rigorosos, quando se trata de punir os danos causados pelos clínicos a seus clientes, sempre que ficar comprovado que eles cometeram erros ou praticaram faltas por negligências, imperícias ou imprudência, no exercício nobre da arte de curar". Respondem os médicos civilmente pelos danos que, no exercício de sua profissão, causem aos seus pacientes. Além disso, há desnecessidade de autorização judicial para cirurgia e transfusão de sangue em paciente necessitado que se recusa à prática desse ato por questão religiosa, por ser isso do estrito cumprimento do dever legal do médico (TJSP, 6 6 Câmara de Direito Privado, AC 264.210-1, Suzano, rel. Testa Marchi, j. 1-8-1996, v.u.).

Ainda de forma mais específica, vez que enfrentou o tema à luz dos hospitais públicos, a procuradora do Distrito Federal Roberta Fragoso Menezes Kaufmann se posicionou pela necessidade de intervenção médica para transfusão de sangue, quando iminente o perigo de morte do paciente, independentemente da manifestação religiosa deste. Confira-se:

A hipótese relativa à colisão entre o direito à vida e a liberdade religiosa nos remete a uma análise, ainda que perfunctória, acerca da relativização dos direitos fundamentais. Isto porque, na espécie, estar-se-ia diante de uma colisão de princípios igualmente relevantes no Ordenamento Jurídico, de estatura constitucional. 
Impende enfatizar, por oportuno, que a renúncia a direitos fundamentais também não se revela absoluta e não pode significar a opção pela morte, sob a responsabilidade do Estado. Tal fato se revela de importância lapidar quando se está diante de situação na qual o paciente submeteu-se, voluntariamente, à tutela estatal, internando-se em hospital público. Nesses termos, o Estado se vincula, por meio do seu dever de proteção, a salvar a vida da paciente, ou a empreender todos os meios possíveis para tal mister.

\section{[...]}

Assim, conclui-se no sentido de que o iminente perigo de vida justifica plenamente a existência do estado de necessidade, de modo que a transfusão de sangue deverá ser efetivada em tais hipóteses. O Poder Público, na medida em que recebe os cidadãos na rede pública hospitalar, assume o importante compromisso de velar pela integridade física dos pacientes, devendo empregar todos os meios necessários ao completo desempenho desse encargo. Em outras palavras: na medida em que tais pacientes ingressam em hospital estatal, relegam a segundo plano a autonomia de decidir e acatam, ainda que de maneira tácita, a conformação dos seus direitos fundamentais pela necessidade estatal de zelar pela sua vida. ${ }^{19}$

De fato, assiste razão à autora supracitada quando sustenta que na medida em que o cidadão se dirige a um hospital, sobretudo público, para buscar tratamento para sua vida, que está em iminente perigo de fenecer, não pode pretender impedir ou ditar o melhor tratamento que o médico deve lhe ministrar. Isto seria, a meu sentir, uma inversão de valores, vez que a paciente, ao se dirigir ao hospital, optou pela salvação de sua vida, cabendo, portanto, método e tratamento finais ao médico.

Outra não parece ser a lição de Nelson Nery Júnior (2003:160), vez que afirma:

no choque entre direitos fundamentais (vida x liberdade), a opção do legislador é a de prestigiar a vida que corre perigo. A predominância do valor norteia a ação de quem se encontra, v.g., por dever legal, na contingência de proceder manobras médicas para salvar o que carece de tratamento médico ou de intervenção cirúrgica imediata.

Os tribunais do país vêm enfrentando a questão jurídica aqui debatida com cautela e, na grande maioria dos casos, têm decidido pela licitude da conduta médica

\footnotetext{
${ }^{19}$ Roberta Fragoso Menezes Kaufmann. Colisão de direitos fundamentais: o direito à vida em oposição à liberdade religiosa. O caso dos pacientes Testemunhas de Jeová internados em hospitais públicos. Jus Navigandi, Teresina, ano 11, n. 1455, 26 jun. 2007. Disponível em: <http://jus2.uol.com.br/doutrina/texto. asp?id=10071>. Acesso em: 10 jan. 2010. A referida autora é mestre em direito pela Universidade de Brasília (UnB) e ex-assessora do ministro do Supremo Tribunal Federal Marco Aurélio Mello.
} 
que se opõe à crença religiosa de uma pessoa para, no intuito de salvar a vida que está em iminente perigo de fenecimento, obrigar-lhe a receber transfusão de sangue.

A propósito, confira-se decisão proferida pelo Tribunal de Justiça do Estado do Rio de Janeiro:

AGRAVO DE INSTRUMENTO. TUTELA ANTECIPADA. Testemunha de Jeová. Recusa à transfusão de sangue. Risco de vida. Prevalência da proteção a esta sobre a saúde e a convicção religiosa, mormente porque não foi a agravante, senão seus familiares, que manifestaram a recusa ao tratamento. Asseveração dos responsáveis pelo tratamento da agravante, de inexistir terapia alternativa e haver risco de vida em caso de sua não realização. Recurso desprovido (Agravo de instrumento no 2004.002.13229, 18a Câmara Cível do TJRJ. Rel. des. Carlos Eduardo Passos, j.: 5-10-2004). ${ }^{20}$

Importante, a meu sentir, transcrever trecho do voto referido supra, da lavra do eminente desembargador Fonseca Passos: “[...] Por fim, não obstante o respeito à convicção religiosa de cada um, entre os dois bens jurídicos tutelados, prevalece a vida sobre a liberdade [...]".

No mesmo sentido, seguem decisões do Tribunal de Justiça do Rio Grande do Sul:

CAUTELAR. TRANSFUSÃO DE SANGUE. TESTEMUNHAS DE JEOVÁ. Não cabe ao Poder Judiciário, no sistema jurídico brasileiro, autorizar altas hospitalares e autorizar ou ordenar tratamentos médico-cirúrgicos e/ou hospitalares, salvo casos excepcionalíssimos e salvo quando envolvidos os interesses de menores. Se iminente o perigo de vida, é direito e dever do médico empregar todos os tratamentos, inclusive cirúrgicos, para salvar o paciente, mesmo contra a vontade deste, de seus familiares e de quem quer que seja, ainda que a oposição seja ditada por motivos religiosos. Importa ao médico e ao hospital é demonstrar que utilizaram a ciência e a técnica apoiadas em séria literatura médica, mesmo que haja divergências quanto ao melhor tratamento. $\mathrm{O}$ judiciário não serve para diminuir os riscos da profissão médica ou da atividade hospitalar. Se a transfusão de sangue for tida como imprescindível, conforme sólida literatura médico-científica (não importando naturais divergências), deve ser concretizada, se para salvar a vida do paciente, mesmo contra a vontade das Testemunhas de Jeová, mas desde que haja urgência e perigo iminente de vida (art. 146, $\S 3^{\circ}$, inc. I, do CP). Caso concreto em que não se verifica tal urgência. $O$ direito

\footnotetext{
${ }^{20}$ Deve-se registrar que ficou vencido o desembargador Marco Antonio Ibrahim.
} 
à vida antecede o direito à liberdade, aqui incluída a liberdade de religião; é falácia argumentar com os que morrem pela liberdade, pois aí se trata de contexto fático totalmente diverso. Não consta que morto possa ser livre ou lutar pela sua liberdade. Há princípios gerais de ética e de direito, que, aliás, norteiam a Carta das Nações Unidas, que precisam se sobrepor às especificidades culturais e religiosas; sob pena de se homologarem as maiores brutalidades; entre eles estão os princípios que resguardam os direitos fundamentais relacionados com a vida e a dignidade humanas. Religiões devem preservar a vida e não exterminá-la (Apelação cível 595.000.373, julgada pela 6 ${ }^{a}$ Câmara Cível do TJRS, rel. des. Sérgio Gischkow Pereira, em 28-3-1995, publicado na RJTJRS 171, p. 384 et seq.).

APELAÇÃO CÍVEL. TRANSFUSÃO DE SANGUE. TESTEMUNHA DE JEOVÁ. RECUSA DE TRATAMENTO. INTERESSE EM AGIR.

Carece de interesse processual o hospital ao ajuizar demanda no intuito de obter provimento jurisdicional que determine a paciente que se submeta à transfusão de sangue.

Não há necessidade de intervenção judicial, pois o profissional de saúde tem o dever de, havendo iminente perigo de vida, empreender todas as diligências necessárias ao tratamento da paciente, independentemente do consentimento dela ou de seus familiares. Recurso desprovido (Apelação cível no 70020868162-2007/Cível, TJRS, 5a Câmara Cível, relator desembargador Umberto Guaspari Sudbrack, j. 22-8-2007).

O Tribunal de Justiça do Estado de São Paulo trilhou o mesmo caminho:

Testemunhas de Jeová. Necessidade de transfusão de sangue, sob pena de risco de morte, segundo conclusão do médico que atende o paciente. Recusa dos familiares com apoio na liberdade de crença. Direito à vida que se sobrepõe aos demais direitos.

Sentença autorizando a terapêutica recusada. Recurso desprovido (Apelação com revisão 1327204900, relator des. Boris Kauffmann, 5ª Câmara de Direito Privado de Férias, j. 26-6-2003, data de registro: 10-7-2003).

EMENTA: Indenizatória - Reparação de danos - Testemunhas de Jeová - Recebimento de transfusão de sangue quando de sua internação - Convicções religiosas que não podem prevalecer perante o bem maior tutelado pela Constituição Federal, que é a vida - Conduta dos médicos, por outro lado, que pautou-se dentro da lei e ética profissional, posto que somente efetuaram as transfusões 
sanguíneas após esgotados todos os tratamentos alternativos - Inexistência, ademais, de recusa expressa a receber transfusão de sangue quando da internação da autora - Ressarcimento, por outro lado, de despesas efetuadas com exames médicos, entre outras, que não merece acolhido, posto não terem sido os valores despendidos pela apelante - Recurso improvido (Apelação com revisão 1234304400, 3ํㅡㄹ Câmara de Direito Privado do TJSP, relator des. Flavio Pinheiro, data do registro 18.6.2002).

Penso ainda ser necessário um último argumento em prol da licitude da conduta do médico que, na iminência de fenecimento da vida, impõe a uma pessoa, mesmo que contra a sua crença religiosa, determinado tratamento. O Código Penal brasileiro, no art. 146, estabelece claramente que tal situação de fato não constitui crime contra a liberdade individual, excluindo a antijuridicidade ou a tipicidade da conduta. Confira-se:

\section{DOS CRIMES CONTRA A LIBERDADE INDIVIDUAL}

\section{$[\ldots]$}

Art. 146. Constranger alguém, mediante violência ou grave ameaça, ou depois de lhe haver reduzido, por qualquer outro meio, a capacidade de resistência, a não fazer o que a lei permite, ou a fazer o que ela não manda:

Pena - detenção, de 3 (três) meses a 1 (um) ano, ou multa.

Aumento de pena:

$\S 1^{\circ}$ As penas aplicam-se cumulativamente e em dobro, quando, para a execução do crime, se reúnem mais de três pessoas, ou há emprego de armas.

$\S 2^{\circ}$ Além das penas cominadas, aplicam-se as correspondentes à violência.

$\S 3^{\circ}$ Não se compreendem na disposição deste artigo:

I - a intervenção médica ou cirúrgica, sem o consentimento do paciente ou de seu representante legal, se justificada por iminente perigo de vida;

II - a coação exercida para impedir suicídio.

Conforme se percebe, a legislação penal brasileira propõe, ainda que implicitamente, o dever do médico de proceder à intervenção médica sempre que a vida do paciente estiver correndo perigo, o que, a meu sentir, inclui a hipótese de transfusão de sangue sem o consentimento do paciente por motivação de crença religiosa.

Penso serem cabíveis as últimas considerações acerca do problema, notadamente quando envolver crianças e adolescentes menores de idade. 
Não fossem os fundamentos desenvolvidos supra suficientes para legitimar a necessidade da intervenção médica - transfusão de sangue - também às crianças e adolescentes filhos das Testemunhas de Jeová - ou mesmo convertidas à referida religião por vontade própria, como decorrência de sua possível "maturidade", penso devam ser analisadas as regras jurídicas traçadas pela Lei Federal no 8.069/90 - Estatuto da Criança e dos Adolescentes (ECA).

A Lei Federal no 8.069/90 garantiu às crianças e adolescentes, como não poderia deixar de ser, o direito à liberdade de crença e religião (art. 16, inciso III). ${ }^{21}$ Todavia, nos arts. $7^{\circ}$ e 11, o ECA normatiza, tal qual o fez a CRFB/88, que toda criança e adolescente têm o direito à proteção integral à saúde e à vida. ${ }^{22}$

Ora, se assim é, creio que com mais razão deve o médico público (ou privado) adotar todas as técnicas e meios disponíveis para salvar a vida de uma criança ou de um adolescente, inclusive transfusão de sangue, se necessário e indispensável, independentemente de sua vontade e/ou de seus responsáveis, fundadas em crenças religiosas ou não, conferindo assim efetividade ao princípio da proteção integral do menor previsto no art. 11 supracitado.

\section{Conclusão}

Em razão das considerações expostas supra, parece-me, à luz das regras constitucionais, legais e regulamentares antes mencionadas, que os médicos, sobretudo aqueles que trabalhem em hospitais públicos, diante de pessoas, maiores ou menores de idade que se dizem Testemunhas de Jeová e por isso recusam tratamento médico que envolva transfusão de sangue (ou de seus derivados), devem procurar atender à manifestação de crença e religião dos pacientes, empreendo, para tanto, todos os esforços e conhecimento técnicos, salientando, porém, que se não houver alternativa para salvar a vida humana, deve a transfusão de sangue ser realizada, ainda que contra o consentimento do doente expressado de forma verbal e/ou por escrito.

\footnotetext{
21 "Art. 16. O direito à liberdade compreende os seguintes aspectos: (...) III - crença e culto religioso." 22 "Art. 7‥ A criança e o adolescente têm direito a proteção à vida e à saúde, mediante a efetivação de políticas sociais públicas que permitam o nascimento e o desenvolvimento sadio e harmonioso, em condições dignas de existência."

"Art. 11. É assegurado atendimento integral à saúde da criança e do adolescente, por intermédio do Sistema Único de Saúde, garantido o acesso universal e igualitário às ações e serviços para promoção, proteção e recuperação da saúde."
} 


\section{Referências}

BARROSO, Luís Roberto. Interpretação e aplicação da Constituição: fundamentos de uma dogmática constitucional transformadora. 4. ed. São Paulo: Saraiva, 2002.

CORTÉS, Julio César Galán. Responsabilidad médica y consentimiento informado. Madrid: Civitas Ediciones, 2001.

DINIZ, Maria Helena. O estado atual do biodireito. São Paulo: Saraiva, 2001.

KAUFMANN, Roberta Fragoso Menezes. Colisão de direitos fundamentais: o direito à vida em oposição à liberdade religiosa. $\mathrm{O}$ caso dos pacientes Testemunhas de Jeová internados em hospitais públicos. Jus Navigandi, Teresina, ano 11, n. 1455, 26 jun. 2007. Disponível em: <http://jus2.uol.com.br/doutrina/texto.asp?id=10071>. Acesso em: 10 jan. 2010.

MIRANDA, Jorge. Manual de direito constitucional. 2. ed. Coimbra: Editora Coimbra, 1998. t. IV.

MORAES, Alexandre de. Direito constitucional. 15. ed. São Paulo: Atlas, 2004.

MORAES, Rodrigo Iennaco de; PIRES, Rodrigo Esteves Santos. Transfusão de sangue em pacientes Testemunhas de Jeová: religião, ética e discurso jurídico-penal (partes 1 e 2). Disponível em: <http://www.direitopenalvirtual.com.br/artigos/ leiamais/default.asp?id=13> e <http://www.direitopenalvirtual.com.br/artigos/ leiamais/default.asp?id=14>. Publicado em: 13 dez. 2006. Acesso em: 12 jan. 2010.

NERY JR., Nelson. Código civil anotado. 2. ed. São Paulo: Revista dos Tribunais, 2003.

PIOVESAN, Flávia. A universalidade e a individualidade dos direitos humanos: desafios e perspectivas. In: BALDI, César Augusto (Org.). Direitos humanos na sociedade cosmopolita. Rio de Janeiro: Renovar, 2004. p. 58-62.

QUEIROZ, Ronaldo Pinheiro de. A natureza jurídica dos conselhos fiscais de profissões regulamentadas. Jus Navigandi, Teresina, ano 10, n. 1211, 25 out. 2006. Disponível em: <http://jus2.uol.com.br/doutrina/texto.asp?id=9082>. Acesso em: 12 jan. 2010.

RAGAZZO, Carlos Emmanuel Joppert. O dever de informar dos médicos e o consentimento informado. 1. ed., 2. tir. Curitiba: Joruá, 2007.

ROBERT, Jacques. Libertés Publiques. Paris: Éditions Monchréstien, 1971 apud SILVA, José Afonso da. Curso de direito constitucional positivo. 15. ed. São Paulo: Malheiros, 1998. p. 201. 
SÁ, Maria de Fátima Freire de; TEIXEIRA, Ana Carolina Brochado. Responsabilidade médica e objeção de consciência. RTDC, n. 21, 2005, p. 130.

SARLET, Ingo Wolfgang. Dignidade da pessoa humana e direitos fundamentais na Constituição Federal de 1988. Porto Alegre: Livraria do Advogado, 2001.

SARMENTO, Daniel. A ponderação de interesses na Constituição Federal. Rio de Janeiro: Lumen Juris, 2000.

SERTÃ, Renato Lima Charnaux. A distanásia e a dignidade do paciente. Rio de Janeiro: Renovar, 2005.

SILVA. José Afonso da. Curso de direito constitucional positivo. 15. ed. São Paulo: Malheiros, 1998. 